\title{
Adam Mazurkiewicz*
}

iD https://orcid.org/0000-0003-3804-6445

\section{Cyfryzacja szkoły w społeczeństwie informacyjnym (na przykładzie polskich rządowych dokumentów i projektów)}

Ekspansywny rozwój technologii informacyjnych, jaki na Zachodzie obserwujemy od przełomu lat pięćdziesiątych i sześćdziesiątych XX wieku nie ograniczał się jedynie do wprowadzenia innowacji w sferze gospodarczej'. Stopniowo wpłynął on jednakże nie tylko na technicyzację życia codziennego, ale przemiany struktur społecznych. Już u kresu lat sześćdziesiątych można dostrzec kształtowanie się zrębów jakościowo nowej formacji kulturowej, określanej mianem „społeczeństwa informacyjnego".

Termin ten wywiedziony został z nauk ekonomicznych, w których służył dookreśleniu wiedzy jako rodzaju zasobu ekonomicznego (prace Fritza Machlupa, głównie The Production and distribution of knowelde in the United States, 1962). Rozważania Machlupa, zreinterpretowane przez pryzmat nauk społecznych, stały się z kolei podstawą dla koncepcji „społeczeństwa wiedzy/informacyjnego”

* Dr hab., prof. UŁ, Uniwersytet Łódzki, Wydział Filologiczny, Instytut Filologii Polskiej i Logopedii, Zakład Dydaktyki Języka Polskiego i Literatury, ul. Pomorska 171/173, 90-236 Łódź, adam.maurkiewicz@uni.lodz.pl

1 W Polsce, ze względu na uwarunkowania zewnętrzne, związane z ideologią i postrzeganiem wytworów cywilizacji Zachodu jako sprzecznych z ideami społeczeństwa socjalistycznego proces ten narasta w przyspieszonym tempie po roku 1989. Należy jednak pamiętać o pierwszych, zaprzepaszczonych szansach rozwoju rodzimej komputeryzacji. W 1958 roku opracowano koncepcję i wdrożono do produkcji komputer XYZ, zaś w latach 1970-1973 minikomputer K-202 o parametrach porównywalnych z komputerami IBM PC (zob.: J.S. Nowak, Uruchomienie produkcji minikomputera K-202. Analiza wstępna, w: High-tech za żelazna kurtyna. Elektronika, komputery i systemy sterowania w PRL, red. M. Sikora, P. Fuglewicz, Wydawnictwo IPN, Katowice-Warszawa 2017, s. 181). W 1986 roku zakończono wdrożenie innego komputera, Mazovia, zaś w 1988 - Poltype. Szerzej na ten temat zob.: K.T. Lewandowski, Termopile polskiej informatyki, „Mówią Wieki” 2002, nr 12, s. 44. 
(jōhōka shakai; 情報化社会) autorstwa Tadao Umesamo (1963), spopularyzowanej przez Kenichi Koyama w pracy Introduction to Information Theory (1968) ${ }^{2}$. Wespół z pracami Daniela Bella (Toward the Year 2000: Work in Progress, 1968; The Coming of Post-Industrial Society: A Venture in Social Forecasting, 1973; The Cultural Contradictions of Capitalism, 1976; The Social Framework of the Information Society, 1980) wymienione tu - pars pro toto - rozprawy stały się fundamentalne dla ukonstytuowania idei społeczeństwa wiedzy.

Wspólne dla ich autorów jest postrzeganie - za Machlupem - wiedzy jako stanu kumulacji kapitału społecznego ${ }^{3}$. Pozostaje on odmienny od dotychczasowych formacji społecznych, właściwych dla społeczeństwa: agrarnego (koncentracja na ziemi), kapitalistycznego (koncentracja na towarze, zaś na późniejszym etapie na wartości symbolicznej przedmiotu, ewokowanej przez pieniądz). Przeciwnie do chronologicznie wcześniejszych, wyszczególnionych tu „epok” społecznych w społeczeństwie wiedzy w centrum zainteresowania pozostaje informacja, która staje się dobrem nadrzędnym, pozwalającym na wymianę towarowo-usługową ${ }^{4}$. $\mathrm{Z}$ tego względu społeczeństwo informacyjne pozostaje - w myśl sugestii Urszuli Słupskiej - w mniejszym stopniu wytworem kultury narodowej, w większym zaś osadzonym w ponadpaństwowych systemach gospodarczych. Jego rozwój wynika z kierunków ewolucji technicznej, stymulującej wektory przemian globalnej gospodarki; dotyczą one m.in. struktury zatrudnienia i form pracy, systemów pro-

2 Z Japonii termin ten przejęty został przez amerykańskich i europejskich badaczy, którzy zastosowali go na określenie przemian zachodzących w dziedzinie technologii komputerowych i telekomunikacji. Szerzej zob.: T. Goban-Klas, Media i komunikowanie. Teorie i analizy prasy radia i telewizji i Internetu, Wydawnictwo Naukowe PWN, Warszawa 1999, s. 286-287.

3 Widać to zwłaszcza w rozważaniach Daniela Bella, traktującego wiedzę jako bazę dla teorii wartości; zob.: tenże, The Coming of Post-Industrial Society: A Venture in Social Forecasting, Basic Books, New York 1973, s. 190. Szerzej na temat koncepcji Bella zob.: Z. Dobrowolski, Koncepcja społeczeństwa informacyjnego Daniela Bella, w: Od informacji naukowej do technologii społeczeństwa wiedzy, red. B. Sosińska-Kalata, M. Przastek-Samokowa, A. Skrzypczak, Wydawnictwo SBP, Warszawa 2005, s. 87-105.

4 Zob. J. Morbitzer, Od motyki do komputera, czyli droga do społeczeństwa informacyjnego, „Konspekt" 2001, nr 8, s. 41-46. Nie inaczej definiuje rolę informacji w społeczeństwie informacyjnym Agnieszka Pawłowska, postrzegająca ją jako kategorie ekonomiczną, zaś produkcje i obieg informacji jako działalność gospodarczą (zob. taż, Władza i uczestnictwo polityczne w społeczeństwie informacyjnym: studium amerykańskie, Wydawnictwo UMCS, Lublin 1995, s. 14). Por. późniejszą o dekadę definicję społeczeństwa informacyjnego: „Do elementarnych [jego - A.M.] cech [...] zalicza się: wytwarzanie, przechowywanie, przekazywanie, pobieranie i wykorzystywanie informacji przez większość obywateli oraz organizacji i miejsc pracy, w szeroko rozumianym zakresie użytku własnego, społecznego w edukacji i działalności zawodowej" (M. Nowina-Konopka, Istota i rozwój społeczeństwa informacyjnego, w: Społeczeństwo informacyjne. Istota, rozwój, wyzwania, red. T. Białobłocki, J. Moroz, M. Nowina-Konopka, L.W. Zacher, Wydawnictwa Akademickie i Profesjonalne, Warszawa 2006, s. 19). 
dukcji i dystrybucji dóbr materialnych, typów organizacji i kultury ekonomicznej ${ }^{5}$. Tym samym w refleksji socjologicznej społeczeństwo informacyjne jest uważane za kolejny poziom ewolucji form społecznych, związany z technicyzacją i komputeryzacją życia. Ów wpływ nowych mediów na definicję zjawiska podkreśla Frank Webster, uznający kluczową ich rolę w procesie tworzenia definicji społeczeństwa informacyjnego ${ }^{6}$.

Zmiany, o których wspominają Słupska i Webster, mają wpływ na nowy kształt współczesnej cywilizacji, przyczyniając się, wraz z rozwojem Internetu i technologii komputerowych, do ukształtowania zjawiska szczególnej wrażliwości, konstytutywnej dla cyberkultury utożsamianej z coraz powszechniejszym paradygmatem kulturowym, właściwym dla społeczeństw Zachodu. Z tego powodu niezbędne staje się uwzględnienie „powinowactw z konieczności” w edukacji zarówno uwikłań społeczeństwa informacyjnego $\mathrm{w}$ globalne sieci powiązań gospodarczych z jednej strony, jak i w postęp technologii cyfrowych? ${ }^{7}$ Tym bardziej, że - w myśl supozycji Agnieszki Olechnickiej - społeczeństwo informacyjne cechuje pojmowanie świata jako złożonego systemu dynamicznego ${ }^{8}$. Konieczny zatem staje się w procesie edukacji i socjalizacji młodego pokolenia nie tylko przekaz

5 Zob. U. Słupska, Rola społeczeństwa informacyjnego w rozwoju współczesnych systemów gospodarczych, „Roczniki Naukowe Wyższej Szkoły Bankowej w Toruniu” 2007, nr 6, s. 109-121.

6 F. Webster, Information Society, w: Encyclopedia of Library and Information Science, red. M.A. Drake, CRS Press, New York 2003 [wyd. 2], t. 2 (Des-Lib), s. 1338 („The most common definition of the information society lays emphasis upon spectacular technological innovation. The key idea is that breakthroughs in information processing, storage, and transmission have led to the application of information technologies (...) in virtually all corners of society").

7 W naszkicowanej tu sieci relacji między edukacją, gospodarką i techniką można dostrzec wyraz determinizmu technologicznego, którego wyrazem pozostaje m.in. konstatacja anonimowego autora: „W XXI wieku, gdy komputery i tablety stały się nieodłącznym elementem naszego społeczeństwa, nie da się uniknąć cyfryzacji. Komputer to w dzisiejszych czasach już nie tylko rozrywka, ale nierzadko ważne narzędzie pracy" (Mąra cyfryzacja szkoły, http:// www.e-math.pl/emath-skorka/materialy/Art3_Cyfryzacja.pdf (dostęp 18.07.2017). Determinizm ten związany jest z akcentowanym przez Langdona Winnera autonomizacji technologii (zob. tenże, Autonomus Technology. Technics-out-of-Control as a Theme in Political Thought, The MIT Press, Cambridge [Massachusetts]-London 1978, s. 74; „In the modern society men and institutions readily embrace inventions and discoveries and take steps to see that they quickly become innovations in the broader spphere of practical activity"). Obserwacja procesów zachodzących w społeczeństwie informacyjnym pozwala na dostrzeżenie wzajemnej relacji między technologią i procesami poznawczymi (zob.: S.B. Srviastava, M.R. Banaji, Culture, Cognition, and Collaborative Networks in Organization, „American Sociological Review” 2011, nr 2, s. 208 [ [interplay among culture, cognition, and social networks in differentiated organisations with norms that wmphasize cross-boundary collaboration"]).

8 Zob.: A. Olechnicka, Regiony peryferyjne w gospodarce informacyjnej, Wydawnictwo Naukowe Scholar, Warszawa 2004, s. 15. 
wiedzy, ale i umiejętności jej zdobywania tak, aby koniec edukacji formalnej stał się dla jednostki punktem wyjścia do samokształcenia, umożliwiającego dostosowywanie się do rynku pracy; nieprzypadkowo przecież w projekcie o charakterze futurologicznej prognozy czytamy: „Jednym z najważniejszych elementów konkurencyjności i innowacyjności jest edukacja"’.

Z tego względu do konstytutywnych cech społeczeństwa informacyjnego należą: oparta na wiedzy gospodarka oraz stymulujący ją wysoki poziom skolaryzacji społeczeństwa ${ }^{10}$. Istotną cechą społeczeństwa informacyjnego jest wysoki jego stopień cyfryzacji, rozumianej jako strategia mająca na celu pełne wykorzystanie możliwości związanych z rozwojem technologii informacyjno-komunikacyjnych i komputeryzacji1".

Cyfryzacja jest zazwyczaj związana z restrukturyzacją gospodarki (głównie sektora usług, który współcześnie - wraz z sektorem rozrywkowym - dominuje nad wytwórczym). Według Mariana Walczaka można wyróżnić cztery etapy rozwoju prowadzącego do osiągnięcia stanu społeczeństwa wiedzy:

- komputeryzacja naukowych projektów badawczych na skalę krajową;

- komputeryzacja zarządzania na szczeblu instytucji rządowych, samorządowych, przedsiębiorstw i podmiotów gospodarczych;

- komputeryzacja wszystkich poziomów masowej edukacji;

- komputeryzacja indywidualna, umożliwiająca jednostce wykorzystywanie informacji zdobytych w Internecie dla rozwiązania własnych problemów lub zaspokojenia ciekawościci ${ }^{12}$.

9 Polska 2030. Trzecia fala nowoczesności. Długookresowa Strategia Rozwoju Kraju, Ministerstwo Administracji i Cyfryzacji, Warszawa 2013, s. 46; możliwość lektury on-line: http:// www.cnz.eurokreator.eu/dokumenty/Polska_2030_Trzecia_fala_nowoczesnosci.pdf (dostęp 18.07.2017).

10 Zob.: W. Furmanek, Szkoła w społeczeństwie wiedzy, „Chowanna” 2012, t. 2: Problemy edukacji w społeczeństwie wiedzy, red. S. Juszczyk, s. 81-94. Oczywiście sam wzrost skolaryzacji nie jest wystarczającym czynnikiem dla rozwoju „gospodarki wiedzy”, nie prowadzi bowiem do zniwelowania nierówności edukacyjnych. Zmienia to dopiero powszechny dostęp do infrastruktury technologicznej (zob.: J. Malikowski, Wyzwania, szanse i zagrożenia niesione przez niektóre trendy cywilizacyjne, „Podstawy Edukacji” 2014, t. 7: Trendy cywilizacyjne, s. 105); interesujące przykłady ilustrujący tezę Jacka Malikowskiego odnajdujemy w szkicu Adrianny Mastalerz-Kodzis, poświęconym rozwojowi społeczeństwa informacyjnego w Polsce; zob.: taż, Dynamika tworzenia społeczeństwa informacyjnego w latach 2001-2011 na przykładzie województw Polski, „Nierówności Społeczne a Wzrost Gospodarczy” 2013, nr 32, s. 182-192.

11 Zob. M. Rojek, Czym jest cyfryzacja?, „CEO.com.pl. Biznes w Praktyce”, https://ceo.com.pl/ marcin-rojek-czym-jest-cyfryzacja-79635 (wpis z dn. 1.10.2016; dostęp 25.07.2017).

12 Zob. M. Walczak, Fundamentalne zmiany kulturowe w wyniku medializacji wszystkich obszarów życia społeczno-gospodarczego i jednostkowego, „Forum Bibliotek Medycznych” 2012, nr 1, s. 63. 
Tym, co zwraca uwagę w rozróżnieniu Walczaka, jest położenie nacisku na oparcie funkcjonowania społeczeństwa na cyfryzacji poszczególnych dziedzin przemysłu i usług oraz konsekwencje rozwoju - związane z "deflacją technologiczną"13 - tzw. Przemystu 4.014. co więcej, dopiero osiągnięcie ostatniego z poziomów, tj. „komputeryzacji indywidualnej”, pozostaje równoznaczne z przejściem od społeczeństwa przemysłowego do społeczeństwa wiedzy. Zarazem przekroczenie tego etapu niemożliwe jest z pominięciem wcześniejszych, stanowiących niejako „przygotowanie” do wdrożenia jednostki w technologiczną codzienność. Nie dziwi zatem, że w obliczu przewidywanego (makro)trendu do wciąż pogłębiającej się komputeryzacji życia codziennego, pojawiają się projekty przemian edukacyjnych stanowiące odpowiedź na tę tendencję. Należy przy tym zaznaczyć, że samo wprowadzenie do szkoły technologii informacyjno-komunikacyjnych nie wystarcza. Musi ono być zresztą podporządkowane celom edukacyjnym ${ }^{15}$.

Jednym z pierwszych, pozostających w sferze wdrożeniowej, był - zainicjowany w 1986 roku, przez ówczesne Ministerstwo Oświaty i Wychowania - projekt stworzenia mikrokomputera Elwro 800 Junior, który mógłby pracować w zamkniętej sieci szkolnej (mamy tu zatem do czynienia z pierwowzorem koncepcji Ogólnopolskiej Sieci Edukacyjnej, 2015) ${ }^{16}$. Z tego względu Elwro 800 Junior produkowano w dwu wersjach: z tzw. kontrolerem (wersja nauczycielska) i bez niego (wersja uczniowska). Ostatecznie jednak zrezygnowano z powszechnego wyposażenia szkół

13 Zob. W. Sztumski, Postęp technologiczny i deflacja odpowiedzialności, „Transformacje” 2015, nr 84/85, s. 167-177.

14 Zob.: W. Paprocki, Koncepcja Przemysł 4.0 i jej zastosowanie w warunkach gospodarki cyfrowej, w: Cyfryzacja gospodarki i społeczeństwa - szanse i wyzwania dla sektorów infrastrukturalnych, red. J. Gajewski, W. Paprocki, J. Pieriegud, Instytut Badań nad Gospodarką Cyfrową, Gdańska Akademia Bankowa, Gdańsk 2016, s. 39-57.

15 Zob. Cyfryzacja polskiej edukacji. Wizje i postulaty, oprac. M. Plebańska, A. Tarkowski, b.m.w. 2016, s. 13; możliwość lektury on-line: https://centrumcyfrowe.pl/wp-content/uploads/2016/07/cyfryzacja-polskiej-edukacji_final.pdf (dostęp 14.07.2017).

Projekt MOiW poprzedziły inne inicjatywy rządowe, które można postrzegać jako jego legitymizację: Opinia nr 18 z 13 grudnia 1983 roku Sejmowej Komisji Nauki i Postępu Technicznego; Postanowienie nr 57 Prezydium Rządu z 5 listopada 1984 roku o zapewnieniu realizacji Uchwaty nr 77/83 Rady Ministrów w sprawie „Elektronizacji gospodarki narodowej do 1990 roku”; Postanowienie Biura Politycznego KC PZPR (Protokół 13/85) w sprawie „Długofalowej koncepcji rozwijania wiedzy i działań zmierzających do sukcesywnego wyposażania uczelni w stosowne urządzenia i materiały". Zawarte w nich deklaracje znalazły wyraz w dwu dokumentach: Programie powszechnej edukacji w zakresie wiedzy informatycznej oraz wdrażania i zastosowania techniki komputerowej w procesach kształcenia w średnich szkołach ogólnokształcących i zawodowych w latach 1986-1990 (Warszawa 1985) oraz Programie rozwoju zastosowań techniki komputerowej w procesach kształcenia w szkołach wyższych w latach 1986-1990 (Warszawa 1985). 
w ów komputer ${ }^{17}$. Rychło też zmiany w życiu społeczno-politycznym i gospodarczym, których symbolem stał się rok 1989, sprawiły, że plany te straciły na znaczeniu w obliczu konieczności transformacji gospodarczej i przejścia od gospodarki opartej na centralnym planowaniu do modelu wolnorynkowego ${ }^{18}$. Toteż, de facto, nowoczesne projekty cyfryzacji szkolnictwa pojawiły się dopiero w opublikowanym przez Ministerstwo Łączności dokumencie ePolska. Plan działania na rzecz rozwoju społeczeństwa informacyjnego w Polsce na lata 2001-2006 (2001) ${ }^{19}$. Jest to

17 Zob.: M. Kosman, Nie tylko wiedźmin. Historia polskich gier komputerowych, Open Beta, Warszawa Marki 2015, s. 28-29. Szerzej na temat planów komputeryzacji za pomocą Elwro 800 Junior zob. R. Poznański, Junior idzie do szkoły, „Bajtek”. Dodatek specjalny „Odrodzenia” i „Sztandaru Młodych" 1987 [sierpień], s. 4.

18 Rok 1989 to oczywiście kulminacja procesów, które rozpoczęły się już wcześniej w związku w rządowymi planami pięciolatki 1986-1990; zob. Polska: reforma, dostosowanie i wzrost. Raport główny, Szkoła Główna Handlowa, Warszawa 1988, s. 58-61.

19 Nie można oczywiście lat 1989-2000 uznać - z perspektywy cyfryzacji szkoły i społeczeństwa za „straconą dekadę”. W 1990 roku założona została w Gdańsku Young Digital Poland Laboratorium Inżynierii Dźwięku (obecnie Young Digital Planet), która w 1995 opublikowała jako pierwsza w Polsce interaktywny kurs języka angielskiego EuroPlus+Flying Colours. W 2000 roku, a zatem jeszcze przed ogłoszeniem dokumenty ePolska. Plan działania na rzecz rozwoju społeczeństwa informacyjnego w Polsce na lata 2001-2006 (2001), firma ta współuczestniczyła w globalnym projekcie edukacyjnym iSzkoła, w ramach którego stworzyła serię multimedialnych podręczników eduROM (informacje za: http://www.ydp.pl/o-nas/\#history (dostęp 14.07.2017). Reprezentatywnym przykładem zmiany społecznego stosunku do cyfryzacji szkolnictwa i postrzegania możliwości wykorzystania w dydaktyce nowych technologii pozostają obserwacje Barbary Kędzierskiej, z których wynika, że w latach 1996-2003 blisko dwukrotnie wzrosła liczba nauczycieli korzystających z możliwości cyfrowych technologii (z 50\% do ponad 95\%); zob.: taż, Kompetencje informatyczne w kształceniu ustawicznym, Instytut Badań Edukacyjnych, Warszawa 2007, s. 191. Wespół z coraz powszechniejszą w latach 1990-1999 modą na gry komputerowe, dane te uświadamiają, w jaki sposób młode pokolenie mentalnie wkraczało w rzeczywistość społeczeństwa wiedzy zarówno dzięki edukacji formalnej, jak i nieformalnej. Co więcej: w eksperymentalnym nurcie sztuki awangardowej, związanej z digital art/ net art, dostrzegamy legitymizację społecznych praktyk i traktowanie ich jako interpretacyjnego punktu odniesienia dla instalacji artystycznych (zob. E. Wójtowicz, Net art, Wydawnictwo Rabid, Kraków 2008). Istotne pozostają też uwagi na temat informatyzacji i edukacji informatycznej w projekcie reformy szkolnej z 1998 roku. W publikacji Reforma systemu edukacji. Projekt (Warszawa 1998) pojawia się ścieżka międzyprzedmiotowa Edukacja informacyjna, obejmująca naukę podstawowych zachowań niezbędnych do funkcjonowania w społeczeństwie informacyjnym (zob. tamże, s. 186). Taką też rolę pełnił przygotowany dla II-IV etapu edukacyjnego przez zespół autorów program kursu technologii informacyjnej; obejmował on m.in. posługiwanie się technologiami informacyjno-komunikacyjnymi, wyszukiwanie i wartościowanie informacji w sieci internetowej, przygotowywanie prostych prezentacji komputerowych (zob. E. Gurbiel, G. Hardt-Olejniczak, E. Kołczyk, H. Krupnicka, M.M. Sysło, Edukacja informatyczna w kształceniu ogólnym. Program nauczania dla szkoły podstawowej, gimnazjum i liceum, WSiP, Warszawa 1998, s. 31-40). Szerzej na temat tego okresu i charakterystycznego dla niego zauroczenia technologiami cyfrowymi 
dokument istotny przede wszystkim dlatego, że koresponduje z inicjatywami europejskimi, m.in. „eEurope - an Information Society for All” („eEurope - Społeczeństwo Informacyjne dla wszystkich”, 1999) oraz „eEurope+” (2001) ${ }^{20}$.

$\mathrm{W}$ jednym $\mathrm{z}$ jego modułów - Inwestowaniu w ludzi i umiejętności - pojawia się odrębny rozdział, poświęcony edukacji w epoce cyfrowej ${ }^{21}$. Celem nadrzędnym edukacji ma stać się - w myśl założeń planu - taki model nauczania/uczenia się, w którym wykorzystane zostaną możliwości cyfrowych mediów, zwłaszcza związane z e-learningiem w jego nurcie "nauczania na odległość”, wykorzystującym media społecznościowe i przenośne urządzenia komunikacyjne (M-learning; mobile learning ${ }^{22}$. Wprowadzają one $\mathrm{w}$ edukacji nową jakość, pozwalając - co podkreśla Piotr Karaś - na tworzenie nowych sytuacji dydaktycznych, ponieważ umożliwiają dostęp do materiałów dydaktycznych w dowolnym miejscu i czasie ${ }^{23}$.

„Nauczanie na odległość” traktowane jest w omawianym tu dokumencie jako remedium na społeczne wykluczenie jednostek pochodzących przede wszystkim z małych środowisk i takich, które nie mają - z różnych względów - możliwości pełnego uczestnictwa w życiu społecznym. Czytamy:

Zdalna edukacja jest ważnym elementem nowoczesnego systemu edukacji, tym bardziej, że adresowana jest głównie do osób dążących do podniesienia poziomu wykształcenia i kwalifikacji zawodowych, osób bezrobotnych, młodzieży z ubogich

zob. J. Laszkowska, Instytucja szkoły wobec fenomenu Internetu, w: Technologia informacyjna w polskiej edukacji, red. B. Siemieniecki, Wydawnictwo Adam Marszałek, Toruń 2002, s. 100-109.

20 Szerzej zob.: M. Gutowska, eEurope - realizacja idei Społeczeństwa Informacyjnego w Unii Europejskiej i w Polsce, 2004, http://waw.warszawa.mazowsze.pl/eeurope/e-europe.html\#_ Toc44411880 (dostęp 14.07.2017).

21 Zob. ePolska. Plan działania na rzecz rozwoju społeczeństwa informacyjnego w Polsce na lata 2001-2006, Warszawa Ministerstwo Gospodarki, 2001, s. 19-23; możliwość lektury on-line: http://www.cyfrowyurzad.pl/gfx/cyfrowyurzad/files/iza/epolska.pdf (dostęp 14.07.2017). Na temat europejskich programów zmierzających do stworzenia społeczeństwa informacyjnego zob. Społeczeństwo Informacyjne w Europie, http://kbn.icm.edu.pl/gsi/europa.htm (dostęp 18.07.2017).

22 Zob. H. Crompton, A historical overview of mobile learning: Toward learner-centered education, w: Handbook of mobile learning, Z.L. Berge, L.Y. Muilenburg, Routledge, Florence 2013, s. 4 („learning across multiple contexts, through social and content interactions, using personal electronic devices"). Sposób wykorzystania mediów społecznościowych (m.in. Facebooka, Naszej-Klasy) w dydaktyce omawia Katarzyna Blak; zob. taż, Portale społecznościowe jako narzędzie edukacyjne, w: Człowiek - media - społeczeństwo, red. E. Musiał, I. Pulak, Wydawnictwo Naukowe UP, Kraków 2011, s. 43-48.

23 Zob.: P. Karaś, Edukacja mobilna jako poszerzone środowisko edukacyjne, w: Człowiek - media - edukacja, red. J. Morbitzer, D. Morańska, E. Musiał, Wydawnictwo Naukowe Wyższej Szkoły Biznesu, Dąbrowa Górnicza 2015, s. 134. 
rodzin i środowisk wiejskich o utrudnionym dostępie do wiedzy oraz do osób niepełnosprawnych ${ }^{24}$.

Aby móc zrealizować tak postawione zadanie konieczne jest - według autorów projektu - działanie wielokierunkowe: przygotowaniu zaplecza technologicznego (w postaci rozbudowy sieci internetowej oraz wyposażenia szkół w sprzęt komputerowy) towarzyszyć miała edukacja nauczycieli (wyrażająca się m.in. modyfikacją programów studiów nauczycielskich poprzez wzbogacenie ich o dodatkowe przedmioty z zakresu posługiwania się nowymi technologiami w pracy z uczniem) oraz tworzenie baz zasobów edukacyjnych (np. tematycznych portali edukacyjnych i multimedialnych aplikacji edukacyjnych). Nie mniejszą rolę w polityce cyfryzacji odgrywa edukacja społeczna dzięki uczynieniu z bibliotek multimedialnych centrów informacji ${ }^{25}$. Jest to istotne przede wszystkim w małych ośrodkach wiejskich, w których szkolna biblioteka odgrywa rolę kulturotwórczą ${ }^{26}$.

Kolejne projekty ministerialne - stworzone zarówno przez Ministerstwo Spraw Wewnętrznych i Administracji, Ministerstwo Nauki i Informatyzacji jak i Ministerstwo Administracji i Cyfryzacji (istniejące w latach 2011-2015; obecnie Ministerstwo Cyfryzacji) oraz Rady do Spraw Informatyzacji Edukacji - uszczegółowiają zakreślone w dokumencie ePolska. Plan działania na rzecz rozwoju społeczeństwa informacyjnego w Polsce na lata 2001-2006 dyrektywy i dookreślając sposoby osiągania poszczególnych celów, jakie pojawiły się w projekcie z 2001 roku. Tym, co charakteryzuje zapisy w nowszych rozporządzeniach, jest akcentowanie szczególnych związków, jakie zachodzą między gospodarką i edukacją w społeczeństwie wiedzy. Przykładem służą uwagi dotyczące źródeł pozyskiwania

24 ePolska..., s. 21. Na temat „nauczania na odległość” zob.: A. Stecyk, Wiedza i nauczanie elektroniczne w społeczeństwie informacyjnym, „Zeszyty Naukowe Uniwersytetu Szczecińskiego. Ekonomiczne problemy usług" 2010, nr 57: E-gospodarka w Polsce. Stan obecny i perspektywy rozwoju, cz. I, s. 44-47; P. Karaś, Edukacja..., s. 133-139.

25 Zob. ePolska..., s. 21. Grzegorz Gmiterek, pisząc o zmieniającej się roli bibliotek we współczesnej rzeczywistości podkreśla walory wynikające z ich jej technicyzacji: „Dzisiejsza biblioteka jest nowoczesnym centrum informacyjnym, miejscem kreatywności, innowacyjności i współpracy” (tenże, Nowe technologie w bibliotekach, „Poradnik Bibliotekarza” [dodatek]: Nowe technologie w bibliotece, s. 4; http://poradnikbibliotekarza.pl/new/pliki/nowe_technologie_net.pdf (dostęp 14.07.2017). Na temat postępów w cyfryzacji bibliotek zob. Działania MKiDN w latach 2008-2015, Ministerstwo Kultury i Dziedzictwa Narodowego, Warszawa 2015, s. 137; możliwość lektury on-line: http://www.mkidn.gov.pl/media/_img/raport/Raport_MKiDN_MINISTERSTWO.pdf (dostęp 18.07.2017).

26 Zob. B. Mruk, Kulturotwórcza rola biblioteki w małych środowiskach na przykładzie biblioteki w Tarnowie Opolskim, „Pomagamy Sobie w Pracy. Opolski Kwartalnik Informacyjno-Metodyczny" 2008, nr 4, s. 57; B. Staniów, Biblioteka szkolna dzisiaj, Wydawnictwo Stowarzyszenia Bibliotekarzy Polskich, Warszawa 2012, s. 187-194. 
funduszy na szerokopasmowy szkolny Internet, niezbędny dla edukacji w społeczeństwie informacyjnym ${ }^{27}$. Pierwotnie jako źródło finansowania projektowano dostępu do sieci internetowej o dużej przepustowości danych w placówkach edukacyjnych (głównie gimnazjach) wyszczególniono ówczesne Ministerstwo Edukacji Narodowej i organizacje pozarządowe ${ }^{28}$.

Tymczasem w projekcie Strategia informatyzacji Rzeczypospolitej Polskiej - ePolska na lata 2004-2006 (2003), opracowanym przez Ministerstwo Nauki i Cyfryzacji czytamy:

Należy dążyć do sytuacji, w której przynajmniej szkoły średnie mogą zaoferować uczniom zajęcia, w czasie których każdy uczeń ma do dyspozycji odrębny komputer. Ponadto istniejące pracownie powinny być dostępne po lekcjach w ramach kół zainteresowań lub jako „otwarte pracownie komputerowe”. Z powodu sytuacji budżetu, integralną częścią projektu powinno być poszukiwanie sponsorów. W szczególności należy pozyskiwać operatorów telekomunikacyjnych do preferencyjnego traktowania szkół korzystających z Internetu²9.

Przyzwolenie na partycypację sektora prywatnego w rozbudowie dostępu szkół do Internetu to nie tylko - i nie przede wszystkim - przejaw „ekonomicznej Realpolitik" ze strony ministerstw odpowiedzialnych za stworzenie w Polsce podstaw społeczeństwa informacyjnego. Wprzęgnięcie gospodarki w służbę edukacji

27 Zob. A. Rychlik, Budowa i eksploatacja szerokopasmowego dostępu do Internetu jako podstawy organizacji społeczeństwa informacyjnego, w: Człowiek - media - edukacja, red. E. Musiał, I. Pulak, Wydawnictwo Naukowe UP, Kraków 2011, s. 336-353.

28 Zob.: ePolska..., s. 22-23. Takie postrzeganie źródeł finansowania procesu komputeryzacji szkoły zdaje się zbieżne z niegdysiejszymi deklaracjami Jerzego Chełchowskiego, współodpowiedzialnego za przygotowanie szkolnictwa do przyjęcia mikrokomputera Junior. W jednej z wypowiedzi deklarował on: „Sprawę Juniora [...] należy traktować w kategoriach patriotycznego obowiązku wobec szkolnictwa, a nie interesu" (za: R. Poznański, Junior..., s. 4). Powyższe uwagi nie oznaczają, że nie mamy do czynienia z upolitycznieniem procesu informatyzacji społeczeństwa (a pośrednio i edukacji). Przeciwnie: hasło edukacji medialnej pojawia się regularnie w kampaniach poszczególnych komitetów wyborczych. Piotr Boroń łączy je z wizją nie tylko programu politycznego poszczególnych kandydatów na parlamentarzystów i prezydenta RP, ale i obrazem nowoczesności, jaki można wysnuć z ich obietnic; zob.: tenże, Wątki edukacji medialnej w zapowiedziach komitetów wyborczych do Parlamentu RP, w: Człowiek - media - edukacja, red. J. Morbitzer, E. Musiał, Wydawnictwo Naukowe UP, Kraków 2014, s. 47-58; tenże, Wątki edukacji medialnej w kampaniach prezydenckich w Polsce w latach 1989-2010, w: Człowiek - media - edukacja, red. J. Morbitzer, D. Morańska, E. Musiał, Wydawnictwo Naukowe Wyższej Szkoły Biznesu, Dąbrowa Górnicza 2015, s. 37-46.

29 Strategia informatyzacji Rzeczypospolitej Polskiej - ePolska na lata 2004-2006, Ministerstwo Nauki i Informatyzacji, Warszawa 2003, s. 33; możliwość lektury on-line: http://kaznowski.blox. $\mathrm{pl} /$ resource/strategia_informatyzacji_rp.pdf (dostęp 14.07.2017). 
(a zarazem urealnienie programów nauczania tak, aby odpowiadały na zapotrzebowanie różnych gałęzi przemysłu i sektora usług) jest przejawem świadomości relacji między ekonomią, nauką i gospodarką, na które wskazywał już Machlup, badając owe powiązania w społeczeństwie amerykańskim ${ }^{30}$.

Tymczasem w ogłoszonym w 2006 roku przez Justynę Osiecką-Chojnacką sprawozdaniu pt. Komputeryzacja szkolnictwa. Sytuacja w Polsce na tle innych krajów Unii Europejskiej czytamy o niedostatecznym (jakkolwiek stopniowo zwiększającym się) wyposażeniu polskich szkół w sprzęt komputerowy i braku przygotowania nauczycieli do prowadzenia zajęć edukacyjnych z wykorzystaniem technologii informacyjnych ${ }^{31}$. Co istotne, zastrzeżenia te pojawiają się w opublikowanym dwa lata później dokumencie pt. Strategia rozwoju społeczeństwa informacyjnego $w$ Polsce do roku 2013 (2008) do podejmowanych w latach 2001-2008 działań, mających na celu stworzenie podstaw społeczeństwa informacyjnego:

Wśród słabych stron mogących hamować rozwój społeczeństwa informacyjnego w Polsce wymienić należy niski stopień wykorzystania technologii informacyjnych i komunikacyjnych w szkolnictwie, niedostateczne powiązanie systemu edukacji z potrzebami rynku pracy oraz niski wskaźnik kształcenia ustawicznego wśród dorosłych $^{32}$.

Uwaga ta zaskakuje tym bardziej, że w dokumencie, będącym punktem odniesienia dla późniejszych projektów za priorytet uznano cyfryzację i edukację permanentną jako ścieżki rozwoju społeczeństwa wiedzy ${ }^{33}$. Nieprzypadkowo przecież

30 Zob. F. Machlup, The Production and Distribution of Knowelde in the United States, Princeton University Press, Princeton 1962, s. 51-206. Co istotne: Machlup pisze o dwu „aktywnościach” ewokowanych przez kombinacje wiedzy i gospodarki: nowa wiedza stymuluje aktywość badaczy, a zarazem postęp technologiczny i gospodarczy („Research and knowelde about how things are, or things could be made, is originated in the mind of the researcher, discover, inventor, or developer; and secondly, this knowelde is produced also in the minds of others"; tamże, s. 145).

31 Zob.: J. Osiecka-Chojnacka, Komputeryzacja szkolnictwa. Sytuacja w Polsce na tle innych krajów Unii Europejskiej, Kancelaria Sejmu. Biuro Studiów i Ekspertyz, Warszawa 2006, s. 14-15; możliwość lektury on-line: http://biurose.sejm.gov.pl/teksty_pdf_06/i-1253.pdf (dostęp 18.07.2017).

32 Strategia rozwoju społeczeństwa informacyjnego w Polsce do roku 2013, Ministerstwo Spraw Wewnętrznych i Administracji, Warszawa, 2008, s. 6.

33 Na istotność komputeryzacji oświaty wskazują też wyniki badań ankietowych Krystyny Polańskiej; zob.: taż, Ocena i skutki komputeryzacji w Polsce w świetle opinii badanych studentów, w: Polskie doświadczenia w kształtowaniu społeczeństwa informacyjnego. Dylematy cywilizacyjno-kulturowe, red. L.H. Haber, Wydawnictwo Akademii Górniczo-Hutniczej, Kraków 2002, s. 469-476. Krytycznie wobec postulatów niewystarczającej informatyzacji polskiej szkoły odniósł się Piotr Soszyński, wskazując na ideologizację tego procesu; zob.: tenże, Cyberkonformizm. Komputeryzacja szkoły jako gra pozorów, „Kultura i Wychowanie” 2014, nr 7, s. 76-82; w kontrapunkcie do tez 
w module projektu ePolska..., poświęconym pracy zawodowej w gospodarce społeczeństwa opartego na wiedzy czytamy:

Doświadczenia krajów wysoko rozwiniętych pod względem ekonomicznym dowodzą, że sukcesy gospodarcze, wysoka pozycja tych krajów na rynku światowym i konkurencyjność gospodarek w coraz większym stopniu zależą od poziomu wiedzy społeczeństwa oraz umiejętności tworzenia i wykorzystywania wiedzy technicznej, ekonomicznej, informatycznej etc. w procesach gospodarczych. Gospodarki krajów wysoko rozwiniętych oparte są o rosnące zasoby ludzi dobrze wykształconych, posiadających umiejętności twórcze i innowacyjne, co jest niezbędnym warunkiem postępu technicznego, gospodarczego i społecznego ${ }^{34}$.

Zawarte w Strategii rozwoju społeczeństwa informacyjnego w Polsce na lata 2007-2013 (2007) wyniki analizy SWOT podjętych w latach 2001-2006 działań związanych z cyfryzacją społeczeństwa wskazują na istotność barier natury ekonomicznej w rozwoju społeczeństwa wiedzy. Należą do nich przede wszystkim wysokie koszty urządzeń cyfrowych i usług telekomunikacyjnych w relacji do zarobków oraz monopolizacja rynku programów i systemów operacyjnych przez jedną firmę ${ }^{35}$. Z kolei w dokumencie Strategia rozwoju społeczeństwa informacyjnego w Polsce do roku 2013 (2008) nacisk położony został na ograniczanie wykluczenia cyfrowego dzięki znoszeniu barier edukacyjnych, ekonomicznych i geograficznych, czyli - de facto - powtórzono postulaty zawarte w projekcie ePolska... oraz założenia przyświecające realizowanemu w latach 2012-2013 programowi Cyfrowa Szkoła ${ }^{36}$. Nie inaczej dookreślone pozostają cele operacyjne w najnowszym dokumencie Ministerstwa Cyfryzacji, Programie zintegrowanej informatyzacji państwa (2016), w którym pojawia się moduł pt. Katalog rekomendowanych e-usług ${ }^{37}$.

Soszyńskiego stoją obserwacje Janusza Janczyka, piszącego o obawach nauczycieli związanych z wprowadzeniem do szkół technologii informacyjno-komunikacyjnych; zob.: tenże, Wybrane meandry procesów cyfryzacji polskiej oświaty, „Dydaktyka Informatyki” 2017, nr 12, s. 87-93.

34 ePolska..., s. 24.

35 Zob. Strategia rozwoju społeczeństwa informacyjnego w Polsce na lata 2007-2013, Ministerstwo Spraw Wewnętrznych i Administracji, Warszawa 2007, s. 54.

36 Zob. Sprawozdanie z rządowego programu rozwijania kompetencji uczniów i nauczycieli w zakresie stosowania technologii informacyjno-komunikacyjnych "Cyfrowa Szkoła”, Ministerstwo Edukacji Narodowej, Ministerstwo Administracji i Cyfryzacji, Warszawa 2014, możliwość lektury on-line: https://men.gov.pl/wp-content/uploads/2014/o2/sprawozdaniecyfrowaszkola-przyjeteprzezrm25_02_2014.pdf (dostęp 18.07.2017); Strategia rozwoju społeczeństwa informacyjnego w Polsce do roku 2013..., s. 5.

37 Zob. Program zintegrowanej informatyzacji państwa, Ministerstwo Cyfryzacji, Warszawa 2016, s. 108-123 (edukacji dotyczą propozycje na s. 119); możliwość lektury on-line: https://mc.gov.pl /files/program_zintegrowanej_informatyzacji_panstwa_1.pdf (dostęp 17.07.2017). Szczególny 
Jaka wizja polskiej szkoły wyłania się z ministerialnych rozporządzeń i dokumentów? Pytanie to - z uwagi na rolę szkoły w socjalizacji jednostek - pośrednio dotyczy kształtu społeczeństwa przyszłości ${ }^{38}$. Jest ono tym bardziej istotne, że - w myśl supozycji Lechosława Hojnackiego - szkoła pozostaje wobec nowych technologii najczęściej bezradna, co sprawia, że dystans między instytucją edukacyjną a środowiskiem, w którym ona funkcjonuje, zaczyna rosnąćc ${ }^{39}$. Zarazem jednak, o czym przekonuje Katarzyna Borawska-Kalbarczyk to właśnie w szkole uczeń znajduje najbardziej dogodne warunki zdobywania wiedzy ${ }^{40}$.

Podczas lektury opracowań i projektów dotyczących cyfryzacji edukacji zwraca uwagę przede wszystkim akcentowane w nich kreatywne wykorzystanie możliwości oferowanych przez technologie cyfrowe ${ }^{41}$. Pozostaje to zgodne zresztą z przeniesieniem uwagi w edukacji z kompetencji „twardych” (tj. związanych z wysoce specjalistyczną wiedzą) na „miękkie” (czyli zasoby wiedzy, umiejętności i postaw decydujących o przewadze konkurencyjnej jednostki, wyrażającej się m.in. w komunikatywności, umiejętności współpracy, przedsiębiorczości) ${ }^{42}$. Taki kierunek przemian edukacyjnych może budzić uzasadniony niepokój, bowiem umiejętno-

nacisk położono w dokumencie na możliwości związane z Naukową i Akademicką Siecią Komputerową (NASK) definiowaną jako instytut badawczo-edukacyjny, w ramach pracy którego (w tzw. Akademii NASK) prowadzone są szkolenia i inicjatywy edukacyjno-popularyzatorskie; zob.: tamże, s. 99.

38 Interesującą perspektywę lekturową osiągamy dzięki wykorzystaniu założeń krytyki retorycznej. W myśl supozycji Jakuba Z. Lichańskiego téchnē rhētorikế pozwala nie tylko na odtworzenie intencji autora wypowiedzi, lecz również jego sposobu wyrażania i wartościowania rzeczywistości (zob. tenże, Retoryka. Historia - Teoria - Praktyka, Wydawnictwo DiG, Warszawa 2007 , t. 1, s. 76-77).

39 Zob. L. Hojnacki, Szkoła wobec nowych technologii - między szansa a zagrożeniem, w: Człowiek - media - edukacja, red. E. Musiał, I. Pulak, Wydawnictwo Naukowe UP, Kraków 2011, s. 125.

40 Zob. K. Borawska-Kalbarczyk, Kompetencje informacyjne uczniów w perspektywie zmian szkolnego środowiska uczenia się, Żak Wydawnictwo Akademickie, Warszawa 2015, s. 459.

41 Zob. K. Majewska, Ocena użyteczności tablicy multimedialnej. Przegląd wyników badań, „Wychowanie Na Co Dzień" 2011, nr 9, s. 29-32; taż, Efektywność interaktywnej formy nauczania z użyciem tablicy multimedialnej, „e-mentor” 2016, nr 1, s. 31-39 (możliwość lektury on-line: https:// repozytorium.umk.pl/bitstream/handle/item/3094/Efektywnosc_interaktywnego_nauczania.pdf?sequence=1 (dostęp 24.08.2017).

42 Zob. B. Kromer, Rozwój kompetencji jako podstawa zwiększania efektywności działalności organizacji, „Zarządzanie i Finanse” 2013, nr 1, s. 371-390. Oczywiście samo kształcenie kompetencji „miękkich” w szkole nie wystarcza, jeśli nie będzie wspierane edukacją nieformalną; zob.: K. Warzecha, Komputer z dostępem do Internetu jako nieodzowne wyposażenie współczesnych gospodarstw domowych - cele korzystania oraz zagrożenie uzależnieniem, „Prace Naukowe Akademii im. Jana Długosza w Częstochowie. Pragmata tes Oikonomias" 2013, z. VII, s. 87-98. 
ści nie zastąpią wiedzy. Zarazem jednak kompetencje „miękkie” pozostają kluczowe dla szybkiego przyswajania potrzebnych w danym momencie informacji; w tym rozumieniu można by zatem zdolność do uczenia się określić jako meta-kompetencję, tj. umiejętność nadrzędną wobec innych ${ }^{43}$.

Innym zagrożeniem społecznym wydaje się wpisane $\mathrm{w}$ projekty położenie nacisku na depersonalizację kontaktów międzyludzkich poprzez zastąpienie ich „e-usługami”. W konsekwencji jednak proces ten - jakkolwiek usprawniający $\mathrm{w}$ istotny sposób komunikację obywatela $\mathrm{z}$ instytucjami życia publicznego - prowadzi jednak do dehumanizacji relacji komunikujących się z sobą jednostek ${ }^{44}$. Niebezpieczeństwo takie związane $\mathrm{z}$ „nauczaniem na odległość”, wynika z braku (bądź

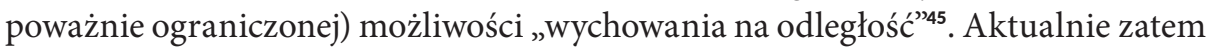

43 Zob. E. Musiał, Rola nauczyciela w kontekście nowej kultury uczenia się, w: Kultura informacyjna w ujęciu interdyscyplinarnym - teoria i praktyka, red. H. Batorowska, Z. Kwiasowski, Uniwersytet Pedagogiczny w Krakowie, Kraków 2016, s. 225.

44 Zob. A. Grabowska, Rodzina wobec przemocy w Internecie, w: Współczesna technologia informacyjna i edukacja medialna, red. T. Lewowicki, B. Siemieniecki, Wydawnictwo Adam Marszałek, Toruń 2005, s. 100-108; R. Solecki, Funkcjonowanie pokolenia cyfrowego w środowisku rówieśniczym, w: Cyberprzestrzeń. Człowiek. Edukacja. Dylematy społeczności cyfrowej, red. J. Bednarek, A. Andrzejewska, Oficyn Wydawnicza Impuls, Kraków 2015, s. 181-192. Nie można zapominać o rewersie sygnalizowanego tu zjawiska, jakim pozostaje wyalienowanie jednostek mających utrudniony dostęp do technologii informacyjno-komunikacyjnych; zob. M. Musioł, Implikacje edukacyjne i społeczne wykluczenia cyfrowego dzieci/nastolatków w wieku drugiego etapu edukacyjnego, w: Cyberprzestrzeń. Człowiek. Edukacja..., s. 153-162.

45 Znamienne pod tym względem jest ambiwalentne postrzeganie konektywizmu, zarówno jako szansy edukacyjnej, jak i zagrożenia wynikającego z braku akcentowania w nim wymiaru etycznego; zob. M. Suwara, O nowej wychowawczej roli Internetu, w: Media w edukacji - szanse i zagrożenia, red. T. Lewowicki, B. Siemieniecki, Wydawnictwo Adam Marszałek, Toruń 2008, s. 112-117; H. Batorowska, Kultura informacyjna w perspektywie zmian w edukacji, Wydawnictwo Stowarzyszenia Bibliotekarzy Polskich, Warszawa 2009, s. 73; A. Mlekodaj, B. Zgama, Aksjologiczna i dydaktyczna perspektywa wykorzystania Internetu w praktyce szkolnej, w: Edukacja a nowe media, red. M. Latoch-Zielińska, I. Morawska, M. Potent-Ambroziewicz, Wydawnictwo UMCS, Lublin 2015, s. 105-114. Jednakże codzienna praktyka i popularność, jaką cieszą się portale „Chomik.pl” i „Torrenty.org”, wskazują na społeczną akceptację dla zachowań niezgodnych z prawem; zob.: M. Svensson, S. Larsson, Social Norms and Intellectual Property: Online Norms and the European Legal Development, Department of Sociology of Law Lund University, Lund 2009, s. 59; P. Toczyski, Aktywni internauci - perspektywa zarzadzania doświadczeniem, w: Obiegi kultury. Społeczna cyrkulacja treści. Raport z badań, Centrum Cyfrowe, Warszawa 2012, s. 89-92 (możliwość lektury on-line: https://creativecommons.pl/ wp-content/uploads/2012/01/raport_obiegi_kultury.pdf (dostęp 24.08.2017); M. deKaminski, M. Svensson, S. Larsson, J.A. Olsson, K. Rönkkö, Studying Norms and Social Change in a Digital Age: Identifying and Understanding a Multisensional Gap Problem, w: Social and Legals Norms. Towards a Socio-legal Understanding of Normativity, red. M. Baier, Routledge, London-New York 2016, s. 309-331; Analiza wpływu zjawiska piractwa treści video na gospodarkę w Polsce, PwC, 
brzmią zastrzeżenia Marka Konieczniaka, postrzegającego proces cyfryzacji szkoły w sposób ambiwalentny ${ }^{46}$. Rację przeto mają badacze, podkreślający konieczność kształtowania w nowej, „cyfrowej” szkole świadomości społecznej szans i zagrożeń wynikających $\mathrm{z}$ obecności technologii w codziennym życiu jej użytkowników ${ }^{47}$. Charakter owych zagrożeń w obrazowy sposób ukazał niegdyś Stanisław Bortnowski, kreśląc w minorowej tonacji obraz „cywilizacji (cyber)technologicznego chaosu”: „Internet już jest i będzie przerażającym śmietnikiem informacyjnym. [...] utrwali stereotypy, błędy i przekłamania informacyjne. [...] Internet zamknie nas w czterech ścianach pokoju, odizoluje od bliźnich, uprzedmiotowi wszystko i wszystkich"48. Do takiego obrazu przyszłości poddanej dyktatowi nowych mediów należy dodać ostrzeżenia neurobiologów, akcentujących wpływ korzystania z technologii informacyjno-komunikacyjnych na rozwój mózgu ich użytkownika. $\mathrm{W}$ procesie tym nie tylko przecież tworzone są nowe sieci neuronalne, ale i ulegają degradacji te połączenia, które rozwijałyby się podczas zdobywania wiedzy tradycyjnymi (tu w rozumieniu: „nie za pomocą komputera i Internetu”) metodami ${ }^{49}$.

b.m.w. 2014, https://www.pwc.pl/pl/publikacje/piractwo/analiza_wplywu_zjawiska_piractwa_tresci_wideo_na_gospodarke_w_polsce_raport_pwc.pdf (dostęp 24.08.2017). Fenomen ten można interpretować przez pryzmat społecznie wyobrażanej „zaradności”, usprawiedliwiającej osiągnięcie w nielegalny sposób doraźnego zysku (zob.: T. Rakowski, Łowcy, zbieracze, praktycy niemocy, słowo/obraz terytoria, Gdańsk 2009, s. 187; badacz opisuje zjawisko m.in. nielegalnego odzysku złomu i wydobycia węgla, jednak mechanizm pozostaje tożsamy).

46 Zob.: M. Konieczniak, Cyfryzacja szkoły a jakość edukacji, „Edukacja i Dialog” 2012, nr 11-12, s. 60-65.

47 Zob.: J. Bednarek, Nowe wyzwania społeczno-edukacyjne cyfrowej szkoły, „TRENDY. Internetowe Czasopismo Edukacyjne" 2013, nr 4, s. 20; http://bc.ore.edu.pl/dlibra/ doccontent?id=573\&dirids=1 (dostęp 18.07.2017); A. Siemińska-Łosko, Negatywne implikacje wprowadzenia technologii informacyjnej do edukacji, w: Wybrane aspekty technologii informacyjnej w edukacji, red. D. Siemieniecka, A. Siemińska-Łosko, Wydawnictwo Adam Marszałek, Toruń 2007, s. 86-106; M. Trzcińska-Król, Zagrożenia wynikajace z użytkowania technologii informacyjnych, w: Cyberprzestrzeń. Człowiek. Edukacja..., s. 209-223.

48 S. Bortnowski, Boję się INTERNETU!, „Polonistyka” 2000, nr 1, s. 54. Co więcej, wraz z rozwojem cyfryzacji, zaczynają ingerować one nie tylko w społeczne relacje interpersonalne, ale i biologiczny wymiar funkcjonowania jednostki; tym samym zaś technika aktualizuje niegdysiejsze dylematy etyczne, które - z uwagi na potencjalne możliwości technologii cyfrowych - wymagają poszukiwania nowych odpowiedzi. Znaczące pod tym względem pozostają pytania stawiane przez filozofię nauki - zob.: A. Kiepas, Etyka jako czynnik ekorozwoju w nauce i technice, „Problemy Ekorozwoju” 2006, nr 2, s. 77-86; A. Żok, Etyka posthumanizmu, „Poznańskie Zeszyty Humanistyczne" 2014, t. XXII, s. 40-43; G. Böhme, Cywilizacja naukowo-techniczna, przekł. A. Romaniuk, „Filozofia i Nauka. Studia Filozoficzne i Interdyscyplinarne” 2014, t. 2, s. 403-419. Zob.: E. Zawisza, Nowe media a mózg dziecka w rozwoju poznawczym - primum non nocere, w: Człowiek - media - edukacja, red. J. Morbitzer, D. Morańska, E. Musiał, Wydawnictwo Naukowe Wyższej Szkoły Biznesu, Dąbrowa Górnicza 2015, s. 408; M. Kozielska, Wpływ Internetu na aktywność mózgu i procesy poznawcze człowieka, w: Edukacja a nowe technologie w kultu- 
Remedium na ową sytuację jest - akcentowana już w programie Cyfrowa Szkoła - integracja technologii cyfrowych z programami nauczania ${ }^{50}$. Istotne też pozostaje takie kształcenie kompetencji zawodowych nauczycieli, aby potrafili oni dostosować przekazywane treści do mentalnych możliwości swych podopiecznych ${ }^{51}$. O tym, do jakiego stopnia szkolenie w zakresie wykorzystania w edukacji nowych mediów pozostaje istotnym aspektem cyfryzacji szkoły, świadczy osobna uwaga, jaką poświęcono modułowi „e-nauczyciel” w projekcie „Cyfrowa Szkoła”52. Uwagi na ten temat pojawiają się zresztą nie tylko w publikacjach dotyczących bezpośrednio szkoły i edukacji, ale i w szerszych projektach, przybliżających plany cyfryzacji społeczeństwa jako jednego z „zadań kluczowych”, np. w Strategii rozwoju społeczeństwa informacyjnego w Polsce na lata 2007-2013 ${ }^{53}$.

Nie mniej jednak ważniejsze niż edukacja cyfrowa nauczycieli może okazać się wprowadzenie do programów szkolnych podstaw retoryki, traktowanej jako

rze, informacji i komunikacji, red. D. Siemieniecka, Wydawnictwo Naukowe UMK, Toruń 2015, s. 167-178; J. Adamkiewicz, Nowe technologie informacyjne w edukacji. Niekoniecznie „cyfrowa demencja", Wydawnictwo Adam Marszałek, Toruń 2016, s. 86-90. Nadal otwarta pozostaje też kwestia, czy (i do jakiego stopnia) nowe technologie uzależniają swych posiadaczy na podobieństwo używek (zob.: M. Jędrzejko, Czy cybertechnologie uzależniaja? - spory nie tylko pedagogiczne, w: Człowiek - media - edukacja, red. J. Morbitzer, E. Musiał, Wydawnictwo Naukowe UP, Kraków 2014, s. 153-164).

50 Zob.: G. Gregorczyk, Technologia informacyjno-komunikacyjna (TIK) w edukacji. Wskazanie problemów, które moga mieć niekorzystny wpływ na wykorzystywanie nowoczesnych technologii w edukacji, w: „Cyfrowa Szkoła”. Założenia komponentu badawczego, red. A. Sekuła, Centrum Cyfrowe Ministerstwa Administracji i Cyfryzacji, Warszawa 2012, s. 123, http://mc.bip.gov.pl/ rok-2012/zalozenia-komponentu-badawczego-cyfrowa-szkola.html (dostęp 18.07.2017).

51 Wyjściem naprzeciw owym potrzebom są studia podyplomowe zorganizowane przez Zakład Systemów Informatycznych Katedry Zarządzania Politechniki Lubelskiej; zob.: J. Smołka, R. Skrzypa, Technologie informacyjne w nauczaniu - studia podyplomowe doskonalace nauczycieli, w: Technologie informacyjne w warsztacie nauczyciela, red. J. Migdałek, M. Zając, Oficyna Wydawnicza Impuls, Kraków 2008, s. 133-141.

52 Zob. Sprawozdanie z rządowego programu..., s. 5-7. Poszerzeniu kompetencji nauczyciela służą również projekty realizowane w ramach Akademii e-Nauczyciela przez Centrum Nowoczesnych Metod i Technologii Edukacyjnych w Wyższej Szkole Biznesu w Dąbrowie Górniczej (zob.: http://wsb.edu.pl/index.php?p=m\&idg=aen,1553 (dostęp 12.09.2017)). Co istotne: kompetencje te nie zastępują, lecz jedynie wspomagają umiejętności, którymi powinien odznaczać się nauczyciel, niezależnie od tego, czy pracuje metodami „tradycyjnymi”, czy za pomocą narzędzi cyfrowych; wskazuje na to zestawienie nauczycielskich kompetencji psychospołecznych, niezbędnych - zdaniem Aleksandry Knych - do prowadzenia "nauczania na odległość”; zob.: taż, Wybrane kompetencje nauczyciela w zakresie e-learningu, „Journal of Technology and Information Education" 2012, nr 3, s. 88-90.

53 Zob. Strategia rozwoju społeczeństwa informacyjnego w Polsce na lata 2007-2013..., s. 15. 
zorientowanie na komunikację i uniwersalność ${ }^{54}$. Dopiero bowiem wówczas, gdy uczniowi stworzone zostaną możliwości rozwoju kompetencji językowo-społecznych, zasadna będzie kontynuacja procesu cyfryzacji szkoły w takim stopniu, w jakim zostało to określone w nowej, obowiązującej od 1 września 2017 roku podstawie programowej, w której czytamy:

Szkoła ma stwarzać uczniom warunki do nabywania wiedzy i umiejętności potrzebnych do rozwiązywania problemów z wykorzystaniem metod i technik wywodzących się z informatyki, w tym logicznego i algorytmicznego myślenia, programowania, posługiwania się aplikacjami komputerowymi, wyszukiwania i wykorzystywania informacji z różnych źródeł, posługiwania się komputerem i podstawowymi urządzeniami cyfrowymi oraz stosowania tych umiejętności na zajęciach $\mathrm{z}$ różnych przedmiotów m.in. do pracy nad tekstem, wykonywania obliczeń, przetwarzania informacji i jej prezentacji w różnych postaciach ${ }^{55}$.

Nie chodzi zatem, by ograniczyć, bądź uniemożliwić uczniowi kontakt z komputerem i technologiami informacyjno-komunikacyjnymi jako narzędziem edu-

54 Zob. B. Bogołębska, Współczesne polskie badania nad retoryką i jej zastosowaniami, „Acta Universitatis Lodziendzis. Folia Litteraria Polonica” 2005, nr 7, s. 5. Nowa podstawa programowa, przygotowana w związku z reformą szkolnictwa w 2017 roku częściowo rozwiązuje kwestię obecności retoryki w szkole, wprowadzając jej elementy na drugim etapie kształcenia (klasy 4-8); zob. Rozporządzenie Ministra Edukacji Narodowej z dn. 14 lutego 2017 r. w sprawie podstawy programowej wychowania przedszkolnego oraz podstawy programowej kształcenia ogólnego dla szkoły podstawowej, w tym dla uczniów z niepełnosprawnością intelektualną w stopniu umiarkowanym lub znacznym, kształcenia ogólnego dla branżowej szkoły I stopnia, kształcenia ogólnego dla szkoły specjalnej przysposabiającej do pracy oraz kształcenia ogólnego dla szkoły policealnej, „Dziennik Ustaw” 2017, poz. 356. Zob. też: Podstawa programowa. Język polski. Szkoła podstawowa, klasy IV-VIII, https://men.gov.pl/wp-content/ uploads/2016/11/podstawa-programowa---jezyk-polski---szkola-podstawowa---klasy-iv-viii-.pdf (dostęp 18.07.2017); A. Waśko, Nowa podstawa programowa języka polskiego dla kl. IV-VIII szkoły podstawowej, https://www.ore.edu.pl/nowa-podstawa-programowa/JĘZYK\%2OPOLSKI/Nowa\% 2opodstawa\%2oprogramowa\%2ojęzyka\%2opolskiego\%2odla\%2okl.\%2olV-VIII\%2oSzkoły\% 2opodstawowej.\%20Prezentacja.pdf (dostęp 18.07.2017). Retoryka, definiowana w przywołanych tu dokumentach jako umiejętność komunikowania się, staje się odpowiedzią na postulaty Kazimierza Czerwińskiego, podkreślającego konieczność odnowienia namysłu nad fenomenologią spotkania w sytuacji szkolnej; zob.: tenże, Zaniedbane aspekty komunikowania w edukacji szkolnej, w: Komunikowanie się w środowisku szkolnym i pozaszkolnym. Nowe trendy i obszary, red. M. Okrasa, W.J. Maliszewski, M. Fiedor, Wydawnictwo Adam Marszałek - Wydawnictwo UMCS, Toruń-Lublin 2015, s. 59-74.

55 Rozporządzenie Ministra Edukacji Narodowej z dn. 14 lutego 2017 r...., s. 12. Sugerowana tu kolejność (pierwszeństwo retoryki przed cyfryzacją) pozostaje zgodna z traktowaniem téchnē rhētorikế jako „probierza” umiejetności posługiwania się językiem (zob. też B. Bogołębska, M. Worsowicz, Retoryka i jej zastosowanie. Podręcznik dla studentów dziennikarstwa i innych kierunków humanistycznych, Wydawnictwo UŁ, Łódź 2016, s. 19). 
kacyjnym, lecz aby sfunkcjonalizować go tak, jak cyfryzacja szkoły nie powinna być celem „samym w sobie”, lecz podporządkowana nadrzędnym celom dydaktycz$n{ }^{56}$. Sama bowiem obecność technologii informacyjno-komunikacyjnych pozostaje niewystarczająca, jeśli nie niesie z sobą świadomości swoich ograniczeń ${ }^{57}$.

\section{Bibliografia}

Adamkiewicz Joanna, Nowe technologie informacyjne w edukacji. Niekoniecznie „cyfrowa demencja", Wydawnictwo Adam Marszałek, Toruń 2016.

Analiza wplywu zjawiska piractwa treści video na gospodarkęw Polsce, PwC, b.m.w. 2014, https://www.pwc.pl/pl/publikacje/piractwo/analiza_wplywu_zjawiska_piractwa_ tresci_wideo_na_gospodarke_w_polsce_raport_pwc.pdf [dostęp 24.08.2017].

56 Zob. Rozporzadzenie Ministra Edukacji Narodowej z dn. 14 lutego 2017 r...., s. 26-27. Co istotne: nie wystarczą ogólnikowe deklaracje w rodzaju zapisanych w opracowaniach dotyczących przemian funkcji szkoły w dobie społeczeństwa informacyjnego; dla przykładu: „Cyfryzacja edukacji jest bardzo istotnym i niezbędnym środkiem do realizacji nadrzędnego celu edukacyjnego, jakim jest rozwój i dobro ucznia oraz nauczyciela. [...] Szkoły, które odnoszą sukcesy, to właśnie takie, które przede wszystkim zdefiniowały swój cel edukacyjny, a następnie realizując go wykorzystują technologię wszędzie tam, gdzie jest to potrzebne i uzasadnione" (Cyfryzacja polskiej edukacji..., s. 2); „[szkoła] powinna mądrze korzystać - na wszystkich przedmiotach - z dobrodziejstw technologii i przyczyniać się do powiększania wirtualnych zasobów edukacyjnych" (NMS. Nowy Model Szkoły, oprac. A. Nizielski, Raciąż, b.d.w, s. 3; możliwość lektury on-line: http://biblioteka. cyfrowaszkola.waw.pl/biblioteka/dla_nauczycieli/pdf/nowy\%20model\%20szkoly.pdf (dostęp 18.07.2017)). W kontekście tych wypowiedzi niepokój budzi komentarz Anny Beaty Kwiatkowskiej, jakim została opatrzona podstawa programowa przedmiotu informatyka, obowiązująca w zreformowanej szkole podstawowej od 1 września 2017 roku. Położony został w nim nacisk na aspekt techniczny, z pominięciem wymiaru wychowawczego edukacji: „Aby realizacja nowej podstawy programowej z informatyki przebiegała prawidłowo i prowadziła do spodziewanych osiągnięć, ważne jest zapewnienie uczniowi dostępu do komputera z odpowiednim oprogramowaniem i możliwością bezpiecznego połączenia z Internetem. Najlepiej byłoby zatem, aby w części dotyczącej programowania oraz przy realizacji innych zagadnień związanych z pracą przy komputerze edukacja informatyczna odbywała się w pracowni komputerowej przystosowanej do wieku dzieci" (taż, Komentarz do podstawy programowej przedmiotu informatyka na I i Il etapie edukacyjnym, w: Podstawa programowa kształcenia ogólnego z komentarzem. Szkoła podstawowa. Informatyka, s. 28; https://men.gov.pl/zycie-szkoly/ksztalcenie-ogolne/podstawa-programowa/podstawa-programowa-materialy-dla-nauczycieli.html [wpis z dn. 13.06.2017; dostęp 27.09.2017]). W obliczu przemian cywilizacyjnych nie wystarczają bowiem deklaracje o wychowawczej roli szkoły i oraz jej miejscu w polityce edukacyjnej państwa (tamże, s. 8).

57 Zob.: W. Kwiatkowska, Jak nauczać w sieci? - analiza dobrych praktyk, w: Technologie edukacyjne w wymiarze praktycyzmu, red. T. Lewowicki, B. Siemieniecki, Wydawnictwo Adam Marszatek, Toruń 2011, t. II, s. 193. 
Batorowska Hanna, Kultura informacyjna w perspektywie zmian w edukacji, Wydawnictwo Stowarzyszenia Bibliotekarzy Polskich, Warszawa 2009.

Bednarek Józef, Nowe wyzwania społeczno-edukacyjne cyfrowej szkoły, „TRENDY. Internetowe Czasopismo Edukacyjne" 2013, nr 4, s. 15-23, http://bc.ore.edu.pl/ dlibra/doccontent?id=573\&dirids=1 [dostęp 18.07.2017].

Bell Daniel, The Coming of Post-Industrial Society: A Venture in Social Forecasting, Basic Books, New York 1973.

Blak Katarzyna, Portale społecznościowe jako narzędzie edukacyjne, w: Człowiek - media - społeczeństwo, red. Emilia Musiał, Irena Pulak, Wydawnictwo Naukowe UP, Kraków 2011, s. 43-48.

Bogołębska Barbara, Współczesne polskie badania nad retoryką i jej zastosowaniami, „Acta Universitatis Lodziendzis. Folia Litteraria Polonica” 2005, nr 7, s. 5-14.

Bogołębska Barbara, Worsowicz Monika, Retoryka i jej zastosowanie. Podręcznik dla studentów dziennikarstwa i innych kierunków humanistycznych, Wydawnictwo UŁ, Łódź 2016.

Böhme Gernot, Cywilizacja naukowo-techniczna, przekł. Adam Romaniuk, „Filozofia i Nauka. Studia Filozoficzne i Interdyscyplinarne” 2014, t. 2, s. 403-419.

Borawska-Kalbarczyk Katarzyna, Kompetencje informacyjne uczniów w perspektywie zmian szkolnego środowiska uczenia się, Wydawnictwo Akademickie Żak, Warszawa 2015.

Boroń Piotr, Wątki edukacji medialnej w kampaniach prezydenckich $w$ Polsce $w$ latach 1989-2010, w: Człowiek - media - edukacja, red. Janusz Morbitzer, Danuta Morańska, Emilia Musiał, Wydawnictwo Naukowe Wyższej Szkoły Biznesu, Dąbrowa Górnicza 2015, s. 37-46.

Boroń Piotr, Wątki edukacji medialnej w zapowiedziach komitetów wyborczych do Parlamentu RP, w: Człowiek - media - edukacja, red. Janusz Morbitzer, Emilia Musiał, Wydawnictwo Naukowe UP, Kraków 2014, s. 47-58.

Bortnowski Stanisław, Boję się INTERNETU!, „Polonistyka” 2000, nr 1, s. 54.

Crompton Helen, A historical overview of mobile learning: Toward learner-centered education, w: Handbook of mobile learning, Zane L. Berge, Lin Y. Muilenburg, Routledge, Florence 2013, s. 3-14.

Cyfryzacja polskiej edukacji. Wizje i postulaty, oprac. Marlena Plebańska, Alek Tarkowski, b.m.w. 2016, https://centrumcyfrowe.pl/wp-content/uploads/2016/07/ cyfryzacja-polskiej-edukacji_final.pdf [dostęp 14.07.2017].

Czerwiński Kazimierz, Zaniedbane aspekty komunikowania w edukacji szkolnej, w: Komunikowanie się w środowisku szkolnym i pozaszkolnym. Nowe trendy i obszary, red. Marzena Okrasa, Wojciech J. Maliszewski, Marian Fiedor, Wydawnictwo Adam Marszałek-Wydawnictwo UMCS, Toruń-Lublin 2015, s. 59-74.

de Kaminski Marcin, Svensson Mans, Larsson Stefan, Alkan Olsson Joanna, Rönkkö Kari, Studying Norms and Social Change in a Digital Age: Identifying and Understanding a Multisensional Gap Problem, w: Social and Legals Norms. Towards 
a Socio-legal Understanding of Normativity, red. Matthias Baier, Routledge, London-New York 2016, s. 309-331.

Dobrowolski Zdzisław, Koncepcja społeczeństwa informacyjnego Daniela Bella, w: Od informacji naukowej do technologii społeczeństwa wiedzy, red. Barbara Sosińska-Kalata, Maria Przastek-Samokowa, Andrzej Skrzypczak, Wydawnictwo Stowarzyszenia Bibliotekarzy Polskich, Warszawa 2005, s. 87-105.

Działania MKiDN w latach 2008-2015, Ministerstwo Kultury i Dziedzictwa Narodowego, Warszawa 2015, http://www.mkidn.gov.pl/media/_img/raport/Raport_ MKiDN_MINISTERSTWO.pdf [dostęp 18.07.2017].

ePolska. Plan działania na rzecz rozwoju społeczeństwa informacyjnego w Polsce na lata 2001-2006, Ministerstwo Gospodarki, Warszawa 2001, http://www.cyfrowyurzad.pl/gfx/cyfrowyurzad/files/iza/epolska.pdf [dostęp 14.07.2017].

Furmanek Waldemar, Szkoła w społeczeństwie wiedzy, „Chowanna” 2012, t. 2: Problemy edukacji w społeczeństwie wiedzy, red. Stanisław Juszczyk, s. 81-94.

Gmiterek Grzegorz, Nowe technologie w bibliotekach, „Poradnik Bibliotekarza” [dodatek]: Nowe technologie $w$ bibliotece, s. 4-8; http://poradnikbibliotekarza.pl/ new/pliki/nowe_technologie_net.pdf [dostęp 14.07.2017].

Goban-Klas Tomasz, Media i komunikowanie. Teorie i analizy prasy radia i telewizji i Internetu, Wydawnictwo Naukowe PWN, Warszawa 1999.

Grabowska Agata, Rodzina wobec przemocy w Internecie, w: Wspótczesna technologia informacyjna i edukacja medialna, red. Tadeusz Lewowicki, Bronisław Siemieniecki, Wydawnictwo Adam Marszałek, Toruń 2005, s. 100-108.

Gregorczyk Grażyna, Technologia informacyjno-komunikacyjna (TIK) w edukacji. Wskazanie problemów, które moga mieć niekorzystny wplyw na wykorzystywanie nowoczesnych technologii w edukacji, w: „Cyfrowa Szkoła”. Założenia komponentu badawczego, red. Aleksandra Sekuła, Centrum Cyfrowe Ministerstwa Administracji i Cyfryzacji, Warszawa 2012, http://mc.bip.gov.pl/ rok-2012/zalozenia-komponentu-badawczego-cyfrowa-szkola.html [dostęp 18.07.2017].

Gurbiel Ewa, Hardt-Olejniczak Grażyna, Kołczyk Ewa, Krupnicka Helena, Sysło Maciej M., Edukacja informatyczna w kształceniu ogólnym. Program nauczania dla szkoły podstawowej, gimnazjum i liceum, WSiP, Warszawa 1998.

Gutowska Monika, eEurope - realizacja idei Społeczeństwa Informacyjnego w Unii Europejskiej i w Polsce, 2004, http://waw.warszawa.mazowsze.pl/eeurope/e-europe.html\#_Toc44411880 [dostęp 14.07.2017].

Hojnacki Lechosław, Szkoła wobec nowych technologii - między szansa a zagrożeniem, w: Człowiek - media - edukacja, red. Emilia Musiał, Irena Pulak, Wydawnictwo Naukowe UP, Kraków 2011, s. 119-126.

http://kbn.icm.edu.pl/gsi/europa.htm [dostęp 18.07.2017].

Janczyk Janusz, Wybrane meandry procesów cyfryzacji polskiej oświaty, „Dydaktyka Informatyki” 2017, nr 12, s. 87-93. 
Jędrzejko Mariusz, Czy cybertechnologie uzależniają? - spory nie tylko pedagogiczne, w: Człowiek - media - edukacja, red. Janusz Morbitzer, Emilia Musiał, Wydawnictwo Naukowe UP, Kraków 2014, s. 153-164.

Karaś Piotr, Edukacja mobilna jako poszerzone środowisko edukacyjne, w: Człowiek - media - edukacja, red. Janusz Morbitzer, Danuta Morańska, Emilia Musiał, Wydawnictwo Naukowe Wyższej Szkoły Biznesu 2015, s. 133-139.

Kędzierska Barbara, Kompetencje informatyczne w kształceniu ustawicznym, Instytut Badań Edukacyjnych, Warszawa 2007.

Kiepas Andrzej, Etyka jako czynnik ekorozwoju w nauce i technice, „Problemy Ekorozwoju" 2006, $\mathrm{nr}$ 2, s. 77-86.

Knych Aleksandra, Wybrane kompetencje nauczyciela w zakresie e-learningu, „Journal of Technology and Information Education" 2012, nr 3, s. 88-90.

Konieczniak Marek, Cyfryzacja szkoły a jakość edukacji, „Edukacja i Dialog” 2012, nr 11-12, s. 60-65.

Kosman Marcin, Nie tylko wiedźmin. Historia polskich gier komputerowych, Wydawnictwo Open Beta, Warszawa-Marki 2015.

Kozielska Maria, Wpływ Internetu na aktywność mózgu i procesy poznawcze człowieka, w: Edukacja a nowe technologie w kulturze, informacji i komunikacji, red. Dorota Siemieniecka, Wydawnictwo Naukowe UMK, Toruń 2015, s. $167-178$.

Kromer Bożenna, Rozwój kompetencji jako podstawa zwiększania efektywności dziatalności organizacji, „Zarządzanie i Finanse” 2013, nr 1, s. 371-390.

Kwiatkowska Anna Beata, Komentarz do podstawy programowej przedmiotu informatyka na I i II etapie edukacyjnym, w: Podstawa programowa ksztatcenia ogólnego z komentarzem. Szkoła podstawowa. Informatyka, s. 28; https://men.gov.pl/ zycie-szkoly/ksztalcenie-ogolne/podstawa-programowa/podstawa-programowa-materialy-dla-nauczycieli.html [dostęp 27.09.2017].

Kwiatkowska Wioletta, Jak nauczać w Sieci? - analiza dobrych praktyk, w: Technologie edukacyjne w wymiarze praktycyzmu, red. Tadeusz Lewowicki, Bronisław Siemieniecki, Wydawnictwo Adam Marszałek, Toruń 2011, t. II, s. 182-195.

Laszkowska Joanna, Instytucja szkoły wobec fenomenu Internetu, w: Technologia informacyjna $w$ polskiej edukacji, red. Bronisław Siemieniecki, Wydawnictwo Adam Marszałek, Toruń 2002, s. 100-109.

Lewandowski Konrad T., Termopile polskiej informatyki, „Mówią Wieki” 2002, nr 12, s. 44.

Lichański Jakub Z., Retoryka. Historia - Teoria - Praktyka, Wydawnictwo DiG, Warszawa 2007, t. 1.

Machlup Fritz, The Production and Distribution of Knowelde in the United States, Princeton University Press, Princeton 1962.

Majewska Kamila, Efektywność interaktywnej formy nauczania z użyciem tablicy multimedialnej, „e-mentor” 2016, nr 1, s. 31-39, https://repozytorium.umk. 
pl/bitstream/handle/item/3094/Efektywnosc_interaktywnego_nauczania. pdf?sequence $=1$ [dostęp 24.08.2017].

Majewska Kamila, Ocena użyteczności tablicy multimedialnej. Przeglad wyników badań, „Wychowanie Na Co Dzień” 2011, nr 9, s. 29-32.

Malikowski Jacek, Wyzwania, szanse i zagrożenia niesione przez niektóre trendy cywilizacyjne, „Podstawy Edukacji” 2014, t. 7: Trendy cywilizacyjne, s. 85-123.

Mastalerz-Kodzis Adrianna, Dynamika tworzenia społeczeństwa informacyjnego w latach 2001-2011 na przykładzie województw Polski, „Nierówności Społeczne a Wzrost Gospodarczy" 2013, nr 32, s. 182-192.

Mądra cyfryzacja szkoty, http://www.e-math.pl/emath-skorka/materialy/Art3_Cyfryzacja.pdf [dostęp 18.07.2017].

Mlekodaj Anna, Zgama Barbara, Aksjologiczna i dydaktyczna perspektywa wykorzystania Internetu w praktyce szkolnej, w: Edukacja a nowe media, red. Małgorzata Latoch-Zielińska, Iwona Morawska, Małgorzata Potent-Ambroziewicz, Wydawnictwo UMCS, Lublin 2015, s. 105-114

Morbitzer Janusz, Od motyki do komputera, czyli droga do społeczeństwa informacyjnego, „Konspekt” 2001, nr 8, s. 41-46.

Mruk Barbara, Kulturotwórcza rola biblioteki w małych środowiskach na przykładzie biblioteki w Tarnowie Opolskim, „Pomagamy Sobie w Pracy. Opolski Kwartalnik Informacyjno-Metodyczny" 2008, nr 4, s. 5-7.

Musiał Emilia, Rola nauczyciela w kontekście nowej kultury uczenia się, w: Kultura informacyjna $w$ ujęciu interdyscyplinarnym - teoria i praktyka, red. Hanna Batorowska, Zbigniew Kwiasowski, Wydawnictwo Naukowe UP, Kraków 2016, s. 225-233.

Musioł Marcin, Implikacje edukacyjne i społeczne wykluczenia cyfrowego dzieci/nastolatków w wieku drugiego etapu edukacyjnego, w: Cyberprzestrzeń. Człowiek. Edukacja. Dylematy społeczności cyfrowej, red. Józef Bednarek, Anna Andrzejewska, Oficyna Wydawnicza Impuls, Kraków 2015, s. 153-162.

NMS. Nowy Model Szkoły, oprac. Andrzej Nizielski, Raciąż, b.d.w, http://biblioteka.cyfrowaszkola.waw.pl/biblioteka/dla_nauczycieli/pdf/nowy\%20model $\% 20$ szkoly.pdf [dostęp 18.07.2017].

Nowak Jerzy S., Uruchomienie produkcji minikomputera K-202. Analiza wstępna, w: High-tech za żelazna kurtyną. Elektronika, komputery i systemy sterowania w PRL, red. Mirosław Sikora, Piotr Fuglewicz, Wydawnictwo IPN, KatowiceWarszawa 2017, s. 181-196.

Nowina-Konopka Maria, Istota i rozwój społeczeństwa informacyjnego, w: Społeczeństwo informacyjne. Istota, rozwój, wyzwania, red. Tomasz Białobłocki, Janusz Moroz, Maria Nowina-Konopka, Lech W. Zacher, Wydawnictwa Akademickie i Profesjonalne, Warszawa 2006, s. 13-59.

Olechnicka Agnieszka, Regiony peryferyjne w gospodarce informacyjnej, Wydawnictwo Naukowe Scholar, Warszawa 2004. 
Osiecka-Chojnacka Justyna, Komputeryzacja szkolnictwa. Sytuacja w Polsce na tle innych krajów Unii Europejskiej, Kancelaria Sejmu. Biuro Studiów i Ekspertyz, Warszawa 2006, http://biurose.sejm.gov.pl/teksty_pdf_06/i-1253.pdf [dostęp 18.07.2017].

Paprocki Wojciech, Koncepcja Przemysł 4.0 i jej zastosowanie w warunkach gospodarki cyfrowej, w: Cyfryzacja gospodarki i społeczeństwa - szanse i wyzwania dla sektorów infrastrukturalnych, red. Jerzy Gajewski, Wojciech Paprocki, Jana Pieriegud, Instytut Badań nad Gospodarką Cyfrową, Gdańska Akademia Bankowa, Gdańsk 2016, s. 39-57.

Pawłowska Agnieszka, Władza i uczestnictwo polityczne w społeczeństwie informacyjnym: studium amerykańskie, Wydawnictwo UMCS, Lublin 1995.

Podstawa programowa. Język polski. Szkoła podstawowa, klasy IV-VIII, https://men. gov.pl/wp-content/uploads/2016/11/podstawa-programowa---jezyk-polski---szkola-podstawowa---klasy-iv-viii-.pdf [dostęp 18.07.2017].

Polańska Krystyna, Ocena i skutki komputeryzacji w Polsce w świetle opinii badanych studentów, w: Polskie doświadczenia $w$ kształtowaniu społeczeństwa informacyjnego. Dylematy cywilizacyjno-kulturowe, red. Lesław H. Haber, Wydawnictwo Akademii Górniczo-Hutniczej, Kraków 2002, s. 469-476.

Polska 2030. Trzecia fala nowoczesności. Długookresowa Strategia Rozwoju Kraju, Warszawa 2013, http://www.cnz.eurokreator.eu/dokumenty/Polska_2030_Trzecia_fala_nowoczesnosci.pdf [dostęp 18.07.2017].

Polska: reforma, dostosowanie i wzrost. Raport główny, Szkoła Główna Handlowa, Warszawa 1988

Poznański Roman, Junior idzie do szkoły, „Bajtek”. Dodatek specjalny „Odrodzenia” i „Sztandaru Młodych” 1987 [sierpień], s. 4.

Program powszechnej edukacji w zakresie wiedzy informatycznej oraz wdrażania i zastosowania techniki komputerowej w procesach kształcenia $w$ średnich szkołach ogólnokształcacych i zawodowych w latach 1986-1990, Warszawa 1985.

Program rozwoju zastosowań techniki komputerowej w procesach kształcenia $w$ szkołach wyższych w latach 1986-1990, Warszawa 1985.

Program zintegrowanej informatyzacji państwa, Ministerstwo Cyfryzacji, Warszawa 2016, https://mc.gov.pl/files/program_zintegrowanej_informatyzacji_panstwa_1.pdf [dostęp 17.07.2017].

Rakowski Tomasz, Łowcy, zbieracze, praktycy niemocy, Wydawnictwo słowo/obraz terytoria, Gdańsk 2009.

Reforma systemu edukacji. Projekt, Warszawa 1998.

Rojek Marcin, Czym jest cyfryzacja?, „CEO.com. pl. Biznes w Praktyce”, https://ceo. com.pl/marcin-rojek-czym-jest-cyfryzacja-79635 (dostęp 25.07.2017).

Rozporzadzenie Ministra Edukacji Narodowej z dn. 14 lutego 2017 r. w sprawie podstawy programowej wychowania przedszkolnego oraz podstawy programowej kształcenia ogólnego dla szkoły podstawowej, w tym dla uczniów z niepetnosprawnościa intelek- 
tualna w stopniu umiarkowanym lub znacznym, kształcenia ogólnego dla branżowej szkoły I stopnia, kształcenia ogólnego dla szkoły specjalnej przysposabiającej do pracy oraz kształcenia ogólnego dla szkoły policealnej, „Dziennik Ustaw” 2017, poz. 356.

Rychlik Andrzej, Budowa i eksploatacja szerokopasmowego dostępu do Internetu jako podstawy organizacji społeczeństwa informacyjnego, w: Człowiek - media - edukacja, red. Emilia Musiał, Irena Pulak, Wydawnictwo Naukowe UP, Kraków 2011, s. 336-353.

Siemińska-Łosko Agnieszka, Negatywne implikacje wprowadzenia technologii informacyjnej do edukacji, w: Wybrane aspekty technologii informacyjnej w edukacji, red. Dorota Siemieniecka, Agnieszka Siemińska-Łosko, Wydawnictwo Adam Marszałek, Toruń 2007, s. 86-106.

Słupska Urszula, Rola społeczeństwa informacyjnego w rozwoju współczesnych systemów gospodarczych, „Roczniki Naukowe Wyższej Szkoły Bankowej w Toruniu” 2007, nr 6, s. 109-121.

Smołka Jan, Skrzypa Renata, „Technologie informacyjne w nauczaniu” - studia podyplomowe doskonalace nauczycieli, w: Technologie informacyjne $w$ warsztacie nauczyciela, red. Jacek Migdałek, Maria Zając, Impuls, Kraków 2008, s. 133-141.

Solecki Roman, Funkcjonowanie pokolenia cyfrowego w środowisku rówieśniczym, w: Cyberprzestrzeń. Człowiek. Edukacja. Dylematy społeczności cyfrowej, red. Józef Bednarek, Anna Andrzejewska, Oficyna Wydawnicza Impuls, Kraków 2015, s. 181-192.

Soszyński Piotr, Cyberkonformizm. Komputeryzacja szkoły jako gra pozorów, „Kultura i Wychowanie" 2014, nr 7, s. 76-82.

Społeczeństwo Informacyjne w Europie, http://kbn.icm.edu.pl/gsi/europa.htm [dostęp 18.07.2017].

Sprawozdanie z rzadowego programu rozwijania kompetencji uczniów i nauczycieli $w$ zakresie stosowania technologii informacyjno-komunikacyjnych „Cyfrowa Szkoła", Ministerstwo Edukacji Narodowej, Ministerstwo Administracji i Cyfryzacji, Warszawa 2014, https://men.gov.pl/wp-content/uploads/2014/02/sprawozdaniecyfrowaszkola-przyjeteprzezrm25_02_2014.pdf [dostęp 18.07.2017], s. 5-7.

Srviastava Sameer B., Banaji Mahzarin R., Culture, Cognition, and Collaborative Networks in Organization, „American Sociological Review” 2011, nr 2, s. 207-233.

Staniów Bogumiła, Biblioteka szkolna dzisiaj, Wydawnictwo Stowarzyszenia Bibliotekarzy Polskich, Warszawa 2012.

Stecyk Adam, Wiedza i nauczanie elektroniczne w społeczeństwie informacyjnym, „Zeszyty Naukowe Uniwersytetu Szczecińskiego. Ekonomiczne problemy usług" 2010, nr 57: E-gospodarka w Polsce. Stan obecny i perspektywy rozwoju, cz. I, s. 39-48.

Strategia informatyzacji Rzeczypospolitej Polskiej - ePolska na lata 2004-2006, Ministerstwo Nauki i Informatyzacji, Warszawa 2003, http://kaznowski.blox.pl/resource/strategia_informatyzacji_rp.pdf [dostęp 14.07.2017].

Strategia rozwoju społeczeństwa informacyjnego w Polsce na lata 2007-2013, Ministerstwo Spraw Wewnętrznych i Administracji, Warszawa 2007. 
Strategia rozwoju społeczeństwa informacyjnego w Polsce do roku 2013, Ministerstwo Spraw Wewnętrznych i Administracji, Warszawa 2008.

Suwara Marek, O nowej wychowawczej roli Internetu, w: Media w edukacji - szanse i zagrożenia, red. Tadeusz Lewowicki, Bronisław Siemieniecki, Wydawnictwo Adam Marszałek, Toruń 2008, s. 112-117.

Svensson Mans, Stefan Larsson, Social Norms and Intellectual Property: Online Norms and the European Legal Development, Department of Sociology of Law Lund University, Lund 2009.

Sztumski Wiesław, Postęp technologiczny i deflacja odpowiedzialności, „Transformacje” 2015, nr 84/85, s. 167-177.

Toczyski Piotr, Aktywni internauci - perspektywa zarzadzania doświadczeniem, w: Obiegi kultury. Społeczna cyrkulacja treści. Raport z badań, Centrum Cyfrowe, Warszawa 2012, s. 89-92, https://creativecommons.pl/wp-content/uploads/2012/01/raport_obiegi_kultury.pdf (dostęp 24.08.2017).

Trzcińska-Król Maria, Zagrożenia wynikajace z użytkowania technologii informacyjnych, w: Cyberprzestrzeń. Człowiek. Edukacja. Dylematy społeczności cyfrowej, red. Józef Bednarek, Anna Andrzejewska, Oficyna Wydawnicza Impuls, Kraków 2015, s. 209-223.

Walczak Marian, Fundamentalne zmiany kulturowe w wyniku medializacji wszystkich obszarów życia społeczno-gospodarczego i jednostkowego, „Forum Bibliotek Medycznych" 2012, nr 1, s. 58-79.

Warzecha Katarzyna, Komputer $z$ dostępem do Internetu jako nieodzowne wyposażenie współczesnych gospodarstw domowych - cele korzystania oraz zagrożenie uzależnieniem, „Prace Naukowe Akademii im. Jana Długosza w Częstochowie. Pragmata tes Oikonomias” 2013, z. VII, s. 87-98.

Waśko Andrzej, Nowa podstawa programowa jezzyka polskiego dla kl. IV-VIII szkoły podstawowej, https://www.ore.edu.pl/nowa-podstawa-programowa/JEZZYK\%20POLSKI /Nowa\%20podstawa\%20programowa\%20języka\%20polskiego\%20dla\%20k1.\%20 IV-VIII\%20Szkoły\%20podstawowej.\%20Prezentacja.pdf [dostęp 18.07.2017].

Webster Frank, Information Society, w: Encyclopedia of Library and Information Science, red. Miram A. Drake, CRS Press, New York 2003 [wyd. 2], t. 2 (Des-Lib), s. 1338.

Winner Langdon, Autonomus Technology. Technics-out-of-Control as a Theme in Political Thought, The MIT Press, Cambridge [Massachusetts]-London 1978.

Wójtowicz Ewa, Net art, Wydawnictwo Rabid, Kraków 2008.

Zawisza Ewa, Nowe media a mózg dziecka $w$ rozwoju poznawczym - primum non nocere, w: Człowiek - media - edukacja, red. Janusz Morbitzer, Danuta Morańska, Emilia Musiał, Wydawnictwo Naukowe Wyższej Szkoły Biznesu, Dąbrowa Górnicza 2015, s. 406-414.

Żok Agnieszka, Etyka posthumanizmu, „Poznańskie Zeszyty Humanistyczne” 2014, t. XXII, s. 40-43. 


\section{Cyfryzacja szkoły w społeczeństwie informacyjnym (na przykładzie polskich rządowych dokumentów i projektów)}

\section{Streszczenie}

Rozwój technologii informacyjnych nie ograniczał się jedynie do wprowadzenia innowacji w sferze gospodarczej; równie istotne były spowodowane nim zmiany zachodzące w życiu społecznym i edukacji. Współcześnie, wraz z postępującym rozwojem technologii cyfrowych, tendencje te pogłębiają się. Tymczasem szkoła pozostaje wobec nowych technologii najczęściej bezradna, co sprawia, że dystans między instytucją edukacyjną a środowiskiem, w którym ona funkcjonuje, zaczyna rosnąć. Remedium na tę sytuację mają być działania wdrażane w ramach rządowych projektów, przygotowujących szkołę do procesu cyfryzacji. Wynika z nich konieczność integracji technologii cyfrowych z programami nauczania. Istotne też jest kształcenie kompetencji zawodowych nauczycieli, aby potrafili oni dostosować przekazywane treści do mentalnych możliwości swych podopiecznych. Nie chodzi bowiem, aby ograniczyć bądź uniemożliwić uczniowi kontakt z komputerem i technologiami informacyjno-komunikacyjnymi jako narzędziem edukacyjnym, lecz aby go sfunkcjonalizować.

Słowa kluczowe: dydaktyka, internet, cyfryzacja, społeczeństwo wiedzy, e-learning

\section{Digitalisation of schooling in the information society (on the basis of Polish government projects and documents)}

\section{Summary}

The development of the information technology was not solely focused on innovating the economic area; the changes it caused in the social and educational spheres were equally important. Nowadays, as the development of IT is still in progress, these 
tendencies are deepening as well. However, schooling is usually hopeless when confronted with the latest technology, which results in the growing distance between the educational institution and the environment in which it functions. A remedy for this problem are to be the actions presented in the government's projects whose aim is to prepare schooling for the process of digitalisation. The main goal is to integrate the information technologies with schooling curriculums. It is also important to train the teachers so that they know how to transfer the knowledge to their students of different ages. The aim is not to restrict or prevent the students from using computers and being exposed to the informational and communicational technologies as an educational tool, but to make them more functional.

Keywords: teaching, internet, digitization, knowledge society, e-learning

Adam Mazurkiewicz, dr hab., prof. UŁ, adiunkt w Zakładzie Dydaktyki Języka Polskiego i Literatury UŁ (od 2003). Naukowo zajmuje się literaturą i kulturą popularną, historią i teorią komiksu, historią literatury fantastycznonaukowej, związkami obiegów kulturowych, przemianami gotycyzmu, recepcją postępu technologicznego. Autor zarysów monograficznych: O polskiej literaturze fantastycznonaukowej lat 1990-2004 (Łódź 2007) oraz Z problematyki cyberpunku. Literatura - sztuka - kultura, (Łódź 2014) oraz artykułów drukowanych m.in. na łamach „Pamiętnika Literackiego”, „Literatury i Kultury Popularnej”, „Literatury Ludowej”, „Folia Litteraria Polonica” i w tomach zbiorowych. 